Table I. Colony-forming units on sedimentation plates

\begin{tabular}{lllll}
\hline & $\begin{array}{l}\text { Ultraclean } \\
\text { zone } \\
(\mathbf{n}=\mathbf{3 0})\end{array}$ & $\begin{array}{l}\text { Instrument } \\
\text { trolley } \\
(\mathbf{n}=15)\end{array}$ & $\begin{array}{l}\text { Periphery } \\
(\mathbf{n}=\mathbf{3 0})\end{array}$ & $\begin{array}{l}\text { Interposed } \\
\text { person } \\
(\mathbf{n}=30)\end{array}$ \\
\hline $\begin{array}{l}\text { Colonies per plate } \\
\text { Median }\end{array}$ & 0 & 0 & 3 & 5 \\
$\begin{array}{l}\text { Range } \\
\text { Mean }\end{array}$ & 0 to 2 & 0 to 2 & 0 to 7 & 0 to 22 \\
$\begin{array}{l}\text { Colonies per } \mathrm{m}^{2} / \text { hour } \\
\text { Mean }\end{array}$ & 0.27 & 0.33 & 3.43 & 7.23 \\
\hline
\end{tabular}

The plates outside the ultraclean zone had a mean count of 3.43 colonies per plate, ten times more than in the ultraclean zone $(\mathrm{p}<0.001)$. The plates in the ultraclean zone with intermittent interposition had a mean count of 7.23 colonies per plate, 27 times more than those without interposition ( $p<0.001)$ and twice as many as those outside the ultraclean zone ( $p=0.009$; Table I).

Discussion. Sedimentation plates offer a better assessment of direct bacterial fallout into a wound than volumetric analysis of air contamination. The sedimentation rate outside the ultraclean zone was similar to that reported for conventionally ventilated theatres (Scheibel, Jensen and Pedersen 1991) but the interposition of head and shoulders into an ultraclean air flow produced double that rate. The size of the increase produced by interposi- tion may explain some of the contradictory results for infection rates in ultraclean air. Our study suggests that a surgeon who leans over a wound in vertical-downflow ultraclean air can expect a 27 -fold increase in direct wound contamination. In operating positions in which interposition is frequent, body-exhaust suits may be especially advantageous.

The authors wish to thank Professor D. C. E. Speller for making available the facilities of the Department of Microbiology, Bristol Royal Infirmary, and also the Glen Hospital, Bristol, for the use of their ultraclean air operating theatres. This work was supported by grants from the South West Regional Health Authority and from the British Orthopaedic Association Wishbone Trust.

No benefits in any form have been received or will be received from a commercial party related directly or indirectly to the subject of this article.

\section{REFERENCES}

Lidwell OM, Lowbury EJL, Whyte W, et al. Effect of ultraclean air in operating rooms on deep sepsis in the joint after total hip or knee replacement: a randomised study. Br Med J 1982; 285; 10-4.

Marotte JH, Lord GA, Blanchard JP, et al. Infection rate in total hip arthroplasty as a function of air cleanliness and antibiotic prophylaxis. J Arthroplasty 1987; 2:77-82.

Salvati EA, Robinson RP, Zeno SM, et al. Infection rates after 3175 total hip and total knee replacements performed with and without a horizontal unidirectional filtered air-flow system. J Bone Joint Surg [Am] 1982; 64-A:525-35.

Scheibel JH, Jensen I, Pedersen S. Bacterial contamination of air and surgical wounds during joint replacement operations: comparison of two different types of staff clothing. J Hosp Infect 1991; 19: 167-74.

\title{
A MOBILITY PROGRESS CHART
}

\section{G. M. SLOWIK, C. L. COLTON}

There is no simple way of recording and displaying the progress or the lack of it of a patient who is mobilising after an operation or a period of bed-rest. We have designed a chart which provides such a graphic display. Method. We grade mobility as follows:

00 - confined to bed, 0 - able to sit out on a chair,

1 - uses a frame for support,

G. M. Slowik, FRCS

Department of Orthopaedic Surgery, Tampa General Hospital, Tampa, Florida, USA.

C. L. Colton, FRCS, Consultant Orthopaedic Surgeon

Department of Orthopaedic and Accident Surgery, University Hospital, Queen's Medical Centre, Clifton Boulevard, Nottingham NG7 2UH, UK.

Correspondence to Mr G. M. Slowik at PO Box 274106, Tampa, Florida 33688-4106, USA.

(C) 1993 British Editorial Society of Bone and Joint Surgery $0301-620 X / 93 / 3 R 70 \$ 2.00$

J Bone Joint Surg [ Br] 1993; 75-B :504-5.

Received 7 May 1992; Accepted 14 August 1992
2 - uses either 2 crutches or 2 sticks,

3 - uses a single crutch or cane,

4 - independent with no aids.

The letters ' $A$ ' and ' $I$ ' are used to denote Assisted or Independent mobilisation, and the amount of weightbearing is recorded by the standard notation: NWB (non-weight-bearing), PWB (partial), and FWB (full).

This information can be noted on a 'MOBILITY CHART' (Fig. 1) which can be included in the standard bedside charts. We used this chart for 100 consecutive patients after lower-limb surgery, and found it to be extremely valuable in the postoperative period.

Discussion. The chart gives an instant impression of postoperative walking ability, and lack of progress is apparent. The grading system allows for ease of communication between medical staff, nurses and physiotherapists, and the chart provides a permanent record of progress. It also helps to motivate the patient towards higher levels of recovery.

No benefits in any form have been received or will be received from a commercial party related directly or indirectly to the subject of this article. 

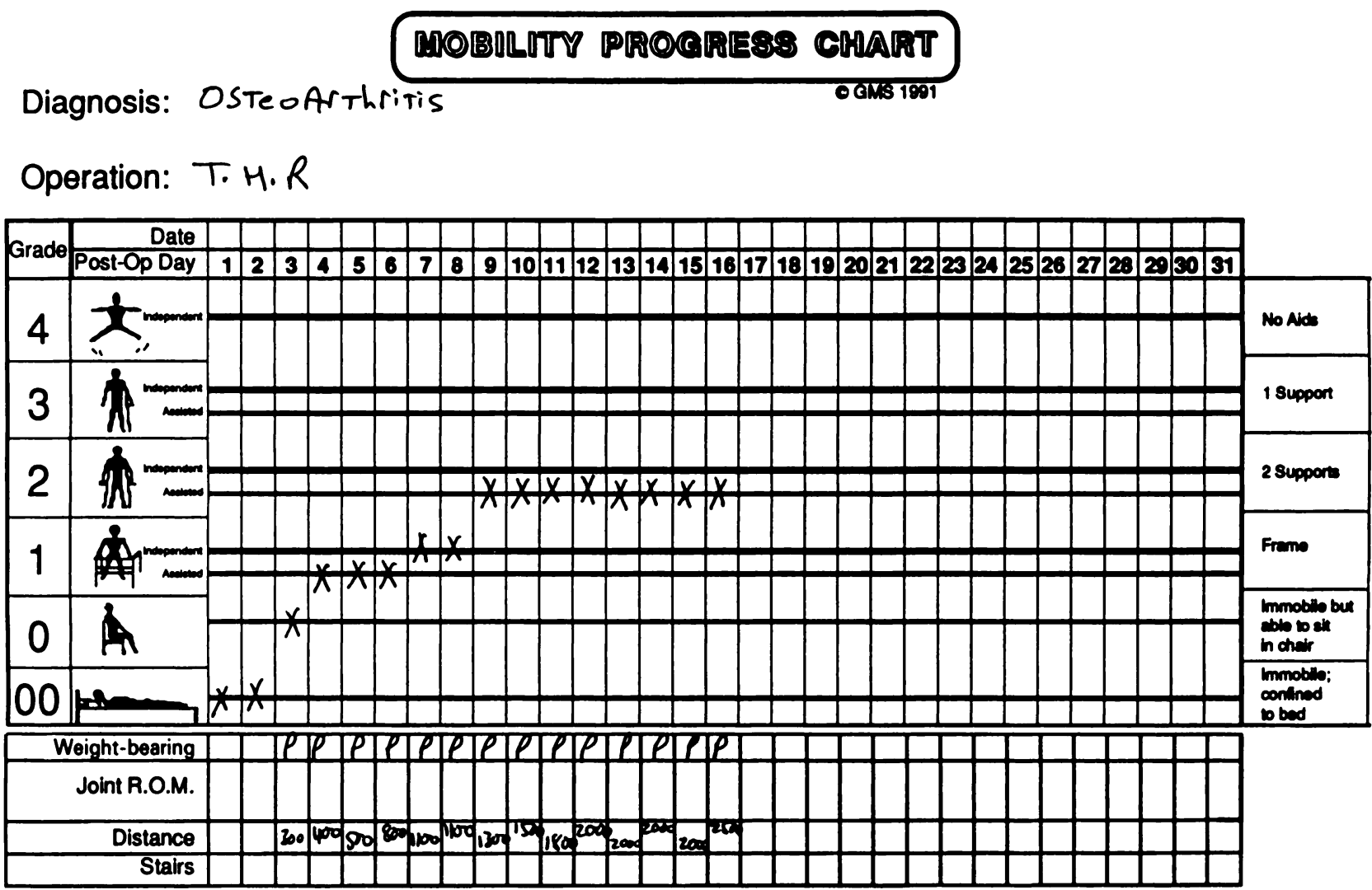

RECORDING MOBILITY PROGRESS: Mark the level of mobility achieved each day by placing an " $X$ " on the independent ( $)$ or assisted ( $(-)$ line corresponding to the appropriate grade.

For weight bearing, insert N, P or F (Elon-weight bearing, Partial weight bearing, or Eull weight bearing.)

Fig. 1

The chart makes it obvious that the patient was using a frame, and needing assistance for partial weight-bearing on day 4 . She became independent of assistance on day 7 . Walking with two supports started on day 9, but there has been no progress since then. On day 9 , for example, she would be classified as grade $2 \mathrm{~A}$.

\title{
ANAPHYLAXIS AFTER INTRA-ARTICULAR INJECTION OF BUPIVACAINE AND METHYLPREDNISOLONE
}

\author{
JONATHAN M. HOPPER, SIMON R. CARTER
}

We report a case of acute anaphylaxis after an intraarticular injection of local anaesthetic and corticosteroid. Case report. A 58-year-old Asian man with intermittent pain due to mild osteoarthritis of the left knee attended

\footnotetext{
J. M. Hopper, BSc, FRCS Ed, Orthopaedic Registrar

Coventry and Warwickshire Hospital, Stoney Stanton Road, Coventry, West Midlands CVI 4FH, UK.

S. R. Carter, FRCS, FRCS G, Consultant Orthopaedic Surgeon Department of Orthopaedics, The Royal Orthopaedic Hospital, The Woodlands Hospital, Bristol Road South, Northfield, Birmingham B31 2AP, UK

Correspondence to Mr J. M. Hopper.
}

(C) 1993 British Editorial Society of Bone and Joint Surgery $0301-620 X / 93 / 3 R 77 \$ 2.00$

J Bone Joint Surg [ Br] 1993; 75-B:505-6.

Received 29 September 1992; Accepted 2 December 1992 as a day case for an intra-articular injection. He had no history of any allergic reaction or aspirin sensitivity. The intra-articular injection of $10 \mathrm{ml}$ of $0.5 \%$ bupivacaine (Marcaine; Astra Pharmaceuticals, Kings Langley, UK) and $80 \mathrm{mg}$ of methylprednisolone (Depo-Medrone: Upjohn, Crawley, UK) was performed in an anaesthetic room by an aseptic technique, which avoided intravascular injection by prior aspiration.

Within ten minutes of the injection, the patient developed acute dyspnoea and complained that his skin was "burning up". He had bronchospasm, tachycardia, hypotension to $90 / 50 \mathrm{mmHg}$ as compared with 145 / $80 \mathrm{mmHg}$ before injection, profuse perspiration and inflammation of the conjunctivae.

He was tilted head-down and given oxygen by a 